\title{
Evaluation of Pumpkin (Cucurbita moschata) Pulp and Seeds Extracts on Gastrointestinal Ulcers Induced by Indomethacin in Rats
}

\author{
Karima Yahia Gad ${ }^{1}$, Tahany El-Sayed Kholief ${ }^{1}$, Heba Barakat ${ }^{1}$, And Shimaa \\ El- masry ${ }^{1}$ \\ ${ }^{1}$ Biochemistry and Nutrition Department, Faculty of Women for Arts, \\ Science and Education Ain Shams University, Cairo, Egypt
}

\begin{abstract}
Peptic ulcer is considered to be one of the most common diseases especially in old age persons due to, the prolonged use of non-steroidal anti-inflammatory drugs (NSAIDs). The present study was done to evaluate the protective and improvement effects of oral administration of each of pumpkin pulp and seed aqueous and ethanolic extracts on gastrointestinal ulcer lesions induced by oral administration of indomethacin in rats. The results showed that indomethacin induced ulceration and inflammations in stomach and small intestine in rats revealed by a significant elevation in xanthine oxidase (XO) and myeloperoxidase (MPO) activities. Moreover, a significant increase in neutrophils infiltration and lipid peroxidation were evidenced by significant increase in the levels of malondialdehyde (MDA)، nitric oxide (NO) with decrease in catalase (CAT) activity and reduced glutathione (GSH) level. However, treatments with pumpkin pulp and / or seed extracts caused a significant decrease in the values of gastric volume, free and total acidity in all groups of rats after administration of pumpkin pulp and / or seeds oil extracts and a significant protective and improvement effects on gastrointestinal status was observed compared to indomethacin pathogenic group.
\end{abstract}

Keywords: Peptic ulcer, indomethacin, pumpkin, xanthine oxidase , myeloperoxidase.

\section{Introduction}

Ulcer is one of the most common defects of the gastric and intestinal walls, which clinically presented as abdominal stress and pain in the upper part of the abdomen and epigastric region. There are two types: gastric ulcers and duodenal ulcers, both types are commonly known as peptic ulcer. Gastric ulcer occurred when the mucosal lining of stomach eroded. Duodenal ulcers or small intestine ulcer occurred by manifestation of superficial, deep, or perforated lesions of small intestine (Dhasan et al ., 2010).

\section{Corresponding author: karima.yahia123@gmail.com}


Ulcers are deep lesions penetrating through the entire thickness of gastrointestinal tract (G.I.T) and muscular mucosa . Ulcers develop due to exposure of stomach lining to the acids produced in the digestive juice. Further, the basic cause of ulceration is an interruption in mucosal integrity (Kumar et al., 2019). About $70-90 \%$ of ulcers are caused by Helicobacter.pylori which is a spiral shaped bacterium that lives in the acidic environment of the stomach (Bhowmik et al.,2010) .Ulcers can also be caused or worsened by drugs such as aspirin and other non-steroidal anti-inflammatory drugs (NSAIDs). Duodenal ulcers are more common rather than stomach ulcers. About $4 \%$ of stomach ulcers are caused by malignant tumor, so multiple biopsies are needed (Tripathi, 2009).

Induction of gastrointestinal toxicity by indomethacin occurs through several mechanisms such as an increase in gastric acid secretion; interfere with mucosal cell regeneration via inhibition of prostaglandin $\mathrm{E}_{2}\left(\mathrm{PGE}_{2}\right.$ ) synthesis, production of free radicals, reduction of gastric nitric oxide level and invasion of activated neutrophils as well as induction of gastric cells apoptosis (Bezerra et al .,2016).

Pumpkin belongs to family Cucurbitaceae and genus cucurbita (Ali and Saddiq, 2012). It is one of the most important and economic vegetable crops and is grown in temperate and tropical regions. All parts of the plant can be used for food, including leaves, pulp, seeds, mature and immature fruits (Zinash et al., 2013).

Many nutritionally important components are present in pumpkin fruit which include polysaccharides, essential amino acids, active proteins, carotenoids and minerals. Moreover it contains a variety of antioxidants, vitamin A, C and E and glycosides, triterpenes and glycosides (EI-Aziz and EI-Kalek, 2011and Borhade, 2012).Moreover, Pumpkin seeds are a great source of protein, minerals, vitamins, and omega-3 fatty acids (Karmes and Haris, 2006).

\section{Aim and objectives of the study:}

Therefore, this study aims to investigate the effect of pumpkin pulp or seeds extract on gastrointestinal toxicity of indomethacin.

\section{Materials and Methods}

\section{Plant materials:}

Ripening pumpkin (Cucurbita moschata) and pumpkin seeds were purchased from Horticulture Research Institute, Ministry of Agriculture, Dokki , Egypt.

\section{1 - Preparation of the pumpkin pulp extract:}

Pumpkin plant was washed with tap water then peeled and Pumpkin seeds were collected. Pumpkin pulp was washed with tap water and cut into slices then put in oven at $70{ }^{\circ} \mathrm{C}$ for dryness. The dried pulp was grounded and the powder dissolved in tap water. The dissolved powder was evaporated on indirect flame then the sticky viscous substance was taken and kept to cool then dissolved in tap water when used (Tahiliani , 2000). The extract was given orally at a dose of $400 \mathrm{mg} / \mathrm{kg}$ body weight twice weekly for 2 weeks (Guha and Sarkar 2008).

\section{2- Preparation of the oil extract of pumpkin seeds:}


The collected pumpkin seeds was washed with water and exposed to dryness by air and sun then in the oven at $52^{\circ} \mathrm{C}$ for 15 min without the shell .The dried seeds were put in electrical grinder then the oil was extracted from the powdered seeds according to AOAC (1990). Pumpkin seeds powder was placed in a soxhlet apparatus and subjected to extraction using ethanol. The solvent was completely removed by evaporation at temperature of $40{ }^{\circ} \mathrm{C}$. The extract was given orally at dose of $400 \mathrm{mg} / \mathrm{kg}$ body weight twice weekly for 2 weeks (Szabo et al., 1985).

\section{2- Biological Experiment:}

\subsection{Animals:}

Adult male albino rats (Sprague-Dawely Strain) weighing (180-200g) were purchased from the breading unit of The Egyptian Organization for Biological Product and Vaccines, Helwan, Egypt. They were kept in stainless steel cages in the well-ventilated animal house. They had access of $12 \mathrm{~h}$ cycle of light /dark and provided with commercial diet and tap water ad-libitum.

\subsection{Induction of Peptic Ulcer:}

Peptic ulcer was induced by oral administration of indomethacin $(5 \mathrm{mg} / \mathrm{kg}$ body weight) by gavage tube once weekly for two weeks according to Ucar et al .( 1998). Indomethacin was dissolved in corn oil (50 mg of indomethacin / $20 \mathrm{ml}$ of corn oil.

\subsection{Experimental Design:}

Rats were divided into 8 groups of 12 rats each as follows:

Group (1): Normal Control group (NCG): rats received tap water (5 ml/ kg body weight) by oral gavage daily.

Group (2): Pathogenic group (PG): rats received the indomethacin $(5 \mathrm{mg} / \mathrm{kg}$ body weight (Szabo et al., 1985).

Groups (3) and (4): Protected pulp group (PPG) and protected seeds group (PSG): rats were received pumpkin pulp and oil seed extracts respectively for 2 weeks then administered indomethacin orally once weekly for 2 weeks.

Group (5): Protected pulp and seeds group (PPSG) : rats received each of pumpkin pulp and seed oil extracts (200mg / kg body weight) twice weekly for 2 weeks then administered indomethacin orally once weekly for 2 weeks

Group (6) and (7) : Improved pulp group (IPG) and Improved seed group (ISG) : rats received indomethacin orally once weekly for 2 weeks then pumpkin pulp and oil seed extracts , respectively twice weekly for 2 weeks.

Group (8): Improved pulp and seed group (IPSG) : rats received indomethacin orally once weekly for 2 weeks then received pumpkin pulp and seed oil extracts ( $200 \mathrm{mg} / \mathrm{kg}$ body) twice weekly for 2 weeks .

\section{Samples Collection}

At the end of the experiment, all rats were sacrificed under ether anesthesia. Stomach and small intestine were separated immediately and washed by saline solution then the wastes were removed from small intestine. Stomach was opened into a graduated cylinder to measure the 
volume of gastric juice. Stomach and small intestine were then blotted on filter paper and weighed; part of them was preserved in $10 \%$ formalin for histopathological examination, and the other parts were stored at $-20{ }^{\circ} \mathrm{C}$ until using for analysis.

\section{Biochemical assays:}

The total and free acidity were determined according to Srikanth and Muralidharan (2009). Gastric and small intestine malondialdehyde (MDA) level was measured colorimetrically according to the method described by Draper and Hadley (1990) .Nitric oxide (NO) level was measured according to the method described by Berkels et al. (2004), catalase activity (CAT) was measured by the colorimetric method described by Aebi (1984), reduced glutathione (GSH) level was measured colorimetrically according to the method described by Beutler (1963). Myeloperoxidase (MPO) and xanthine oxidase (XO) enzyme activities were measured by a quantitative sandwich enzyme immune assay as described by Roelofs (2006) and Kalita et al. (2015) and Sadi (2015), respectively using elisa kits from Cusabio Company, China.

\section{Statistical Analysis:}

All mean values were analyzed according to the Statistical Package for Social Science Program (S.P.S.S.9). One Way analysis of Variance (ANOVA) was used. The difference among groups means were tested using the Least Significant Differences (LSD) at $(\mathrm{P}<0.05)$.Values was expressed as the Mean \pm Standard Deviation (S.D) (Levesque, 2007).

\section{RESULTS}

\section{Influence of pumpkin (Cucurbita moschata) pulp and or oil seeds extracts on gastric volume, total and free acidity:}

Data represented in table (1) showed that rats which received indomethacin had a significant increase $(\mathrm{P}<0.05)$ in the gastric volume, free and total acidity values as compared to normal control group. Whereas, oral administration of the pre and post doses of pumpkin pulp and or seeds oil extracts to improved and protected groups had significantly $(P<0.05)$ decreased gastric volume, free and total acidity as compared to the indomethacin administered pathogenic group $(\mathrm{PG})$.In addition there were no significant differences $(\mathrm{P}>0.05)$ between the protected and improved groups.

\section{Influence of pumpkin (Cucurbita moschata) pulp and or seeds oil extracts on the oxidative biomarkers xanthine oxidase (XO) and myeloperoxidase (MPO) in small intestine:}

Table (2) clarified that indomethacin pathogenic group $(\mathrm{PG})$ had a significant $(\mathrm{P}<0.05)$ increase in the intestinal activities of XO and MPO enzymes as compared to normal control group. On the other hand, there was a significant reduction in XO, MPO activities in all protected and improved groups (PPG, PSG, PPSG, IPG, ISG and IPSG ) which were fed on pumpkin pulp and or oil seeds extracts in either pre or post doses, compared to the pathogenic group (PG). 


\section{Influence of pumpkin (Cucurbita moschata) pulp and or seeds extracts on anti-oxidant} biomarkers reduced glutathione (GSH) and catalase (CAT) of the small intestine and stomach tissues:

Moreover, table (3) demonstrated that there was a significant $(\mathrm{P}<0.05)$ decrease in GSH level and CAT activity of the stomach and small intestine in pathogenic group (PG) which received indomethacin, compared to normal control group (NCG). On the other hand, the pre and post doses of pumpkin pulp and / or oil seeds extracts caused a significant increase (P < 0.05) of both the stomach and small intestine activity of CAT and level of GSH in all of the protected and improved groups, compared to the pathogenic group.

4. Influence of pumpkin pulp and or oil seeds extract on oxidative biomarkers malondialdehyde (MDA) and nitric oxide (NO) in small intestine and stomach:

Compared to normal group, indomethacin pathogenic group exhibited a significant elevation $(\mathrm{P}<0.05)$ in the levels of MDA and NO in the small intestine and stomach tissues as shown in table (4). Whereas, oral administration of pumpkin pulp and / or oil seeds extracts in all protected and improved groups either in the pre or post doses manifested a significant $(\mathrm{P}<$ $0.05)$ decrease in the level of MDA and NO, compared to indomethacin pathogenic group (PG).

\section{Discussion}

\section{Effect of indomethacin on biochemical parameters in experimental animals:}

The present study showed that indomethacin administration increased the gastric volume and altered its secretions. These results emphasized the ulcer induction.

The increment in the values of gastric volume and free and total acidity following indomethacin administration were due to the decreased thickness of GIT mucosal layers resulting from inhibition of cyclooxygenase -1 secretion. The increased amount of gastric juice produced by gastric cells lead to erosion of this mucosal layer due to the decreased amount of bicarbonate which is secreted to neutralize hyperacidity (Cryer and Feldman, 1998).

These findings were evidenced by Furst et al. (2011) who proved that indomethacin had many side effects on alimentary canal due to its inhibitory effect on prostaglandins synthesis. It can damage stomach tissue by increasing gastric acid and pepsin activity. Moreover, indomethacin encourages direct adherence of neutrophils to the gastric endothelium, blocking micro vessels with subsequent decrease in mucosal blood flow leading to ulceration (Shim and Kim, 2016).

Oral administration of indomethacin caused a significant $(\mathrm{P}<0.05)$ hyperactivity in the stomach and small intestine XO and MPO, compared to normal control group. These elevations may be due the inflammation in the mucosal layer, indomethacin caused loss of membrane proteins and phospholipids content of the mucosal layers that affected hydrophobicity of mucosal coat adherent to the mucosal cell surface that cause decrease in mucosal thickness and ulceration . Halici et al. (2005) indicated that the oral administration of indomethacin caused 
peroxidation of the mucosal membrane phospholipids of the gastrointestinal tract leading to decrease in its thickness. Then the small intestine tissues are exposed to reactive oxygen species ( ROS), which lead to inflammation and neutrophils infiltration that resulted in elevation of XO and MPO activities as occurred in the pathogenic group (PG). They added that xanthine oxidase is a source of ROS, because it blocks the mucosal membranes oxidant systems leading to ROS formation and increase the action of oxidative stress so that ulceration occurred

In the present study, the oral administration of indomethacin caused reduction in GSH level of stomach and small intestine. These results may be due to the decreased thickness of the gastrointestinal mucosal membrane and reduction of mucus secretion. More cytokines is produced, in addition to, neutrophils infiltration hence, more amount of cellular GSH is utilized in order to scavenge the free radicals produced in response to inflammation and ulceration.

This explanation is emphasized by Gohsal et al.(2016) who concluded that indomethacin disable the action of $\mathrm{GSH}$, as a proton donor and scavenger of the superoxide free radicals.

Miura et al. (2002) reported that indomethacin may also produce superoxide anion via reacting with $\mathrm{H}_{2} \mathrm{O}_{2}$ by peroxidases present in tissue. This superoxide might damage the membranes and causes the ulcer by increasing lipid peroxidation, which has an important role in the occurrence of gastric damage apart from the inhibition of cyclooxygenase (COX) enzymes. Thus, in the treatment of ulceration, the concentration of $\mathrm{H}_{2} \mathrm{O}_{2}$ in tissue must be reduced quickly to inhibit the lipid peroxidation caused by indomethacin. Hydrogen peroxide $\left(\mathrm{H}_{2} \mathrm{O}_{2}\right)$ is a substrate of catalase (CAT) enzyme its increase will activate the CAT enzyme in damaged gastric cells to combat it.

Raji et al. (2011) found that CAT has a protective character against the action of indomethacin due to its antioxidant activity. They added that CAT has been shown to increase the synthesis of prostaglandin which might further contribute to the gastro-protection of the gastric mucosa.

Oxidative stress occurred in the induced gastric ulcers group and is considered to be one of the mechanisms involved in indomethacin-induced ulcers (Adhikary et al., 2011). Results of the study made by EL-Ashmawy et al. (2016 a) clarified that MDA level was significantly elevated while GSH level was significantly decreased in gastric tissues of the indomethacin induced rats , compared to normal values. Oxidative stress is produced as a result of increasing levels of ROS in gastric tissues, which cause injury to the gastric tissue by damaging membranes and cellular biomolecules such as proteins, DNA and lipids, hence cellular content of GSH is depleted (Suzuki et al., 2012 and Badr and Al-Mulhim, 2014).

The present results demonstrated that rats suffering from induced ulcer by indomethacin had a significant increase in the level of MDA, compared with the normal control group, an indication for the high peroxidation state in their mucosal membrane. 
El-Ashmawy et al. (2016 a) and Sivalingam et al. (2007) found that the elevated level of MDA was due to the action of indomethacin on gastrointestinal mucosal layers of stomach and small intestine. They clarified that their thickness were decreased and their phospholipids content were peroxidized.Thus, their integrity and membrane fluidity were lost allowing the cells to be susceptible to any pathogens.

Moreover, Chen et al. (2005) concluded that the decreased activity of the free radical scavenging enzyme CAT and GSH level suggested the presence of oxidative stress, which was produced in response to the administration of indomethacin. The increase in the generation of free radicals leads to the oxidation of lipids and proteins which are important components of bio membranes. Such changes altered the bio membranes, resulted in impairment of the functions of these structures, and increased the level of MDA .

Results obtained from the present study indicated an elevation in NO level in stomach and small intestine in indomethacin pathogenic group as a marked sign of inflammation. The inflammatory and ulcerative effects of indomethacin in the stomach and small intestine, associated with increased oxidative stress, decreased blood flow in the mucosal endothelium and decreased, the mucus secretion.

Abdel-Raheem (2010) demonstrated that Indomethacin affect on NO level occurred through its ability to up-regulate endothelin-1, a factor that led to reduction in the release of endothelial NO, causing loss of mucosal integrity, an event that is normally maintained by a presence of NO.

Albayrak et al. (2015) clarified that when inflammation occurred, in response to this action neutrophils cell infiltration occurred because of increase in the activities of MPO, so that level of NO increased in order to decrease neutrophils adhesion. Also the prostaglandins (PG) level in the stomach increased, to regulate gastric blood flow, decrease neutrophil adhesion and to regulate the mucosal protection mechanism and suppress the increased MPO activity after the administration of indomethacin.

The current study agreed with EL-Ashmawy et al.(2016 b) who showed that a single acute oral dose of indomethacin induced gastric acidity, ,significantly increased levels of gastric tumor necrosis factor (TNF)- $\alpha$, MDA, significantly decreased level of gastric ( $\left.\mathrm{PGE}_{2}\right)$, GSH and nitric oxide (NO), compared to normal control stomachs.

\section{Influence of pumpkin (Cucurbita moschata) pulp and/or seeds oil extracts on biochemical parameters in gastrointestinal ulcers induced in experimental rats:}

Pumpkin pulp has high content of carotenoids, which have many health benefits through different mechanisms-of-action. Also, the pulp has high antioxidant activities that protect cells and tissues from damage due to free radicals and singlet oxygen and providing enhancement of the immune function (Xavier and Perez-Galvez, 2016). Also, pumpkin seeds oil contains high 
antioxidant vitamins like tocopherol and carotenoid along with sufficient oxidative stability (Hernández-Santos, et al., 2016).

The results of the current study show that free and total acidity values decreased after administration of pumpkin seed oil extract and aqueous pulp extract either alone or in combination. This effect of pumpkin extracts were due to its content of anti-oxidants especially pumpkin seed oil which contains phytosterlos such as sistosterol and antioxidant vitamins and provitamins like tochopherol. In the stomach tissues the improved effect of pumpkin seed oil extract and aqueous extract of pumpkin pulp appeared to be more than protective effect. While in small intestine the two extracts of pulp and seed have the same action. This emphasizes that pumpkin extracts protect the mucosal cells from the action of superoxide free radicals and decreased the action of indomethacin and occurrence of inflammation and ulceration in both stomach and small intestine.

Mohamed and Abd El-fattah (2014) found that administration of pumpkin seed oil has anti -inflammatory, anti-secretory and antioxidant properties that signify pumpkin oil as antiulcergenic agent through decreasing the gastric volume in rats ulcered by aspirin.

High concentration of $\alpha$-tocopherol or vitamin $\mathrm{E}$ in pumpkin seed oil retards lipid peroxidation by acting as an inhibitor of propagation of lipid oxidation and reduction of free ROS. The antioxidant activity of tocopherols would be due to scavenging the peroxyl radicals, because it acts as hydrogen donor and react with free radicals to form the tocopheroxyl radical, also through scavenging superoxide and hydroxyl radicals. Therefore, it is a fat-soluble antioxidant that is ensuring this protection and help in wound healing process (Musalmah et al.,2002). $\beta$-sitosterol is present in pumpkin seed oil and has been reported to possess prominent angiogenic activity that promote fibroblast multiplication and consequently the healing activity ( Loizou et al.,2010). In addition, pumpkin seed oil contain a high amount of polyunsaturated fatty acids such as linoleic acid and linolenic acid. Linoleic acid, a precursor of arachidonic acid, is important in the synthesis of inflammatory mediators (prostaglandins, thromboxanes, and leukotrienes) which accelerate the inflammatory process. Thus, they enhance cellular migration and fibroblastic differentiation that lead to speed of wound healing (Bardaa et al., 2016).

Pumpkin pulp and seeds oil extracts contain antioxidant compounds that have the ability to reduce the effect of oxidative stress, initiated after induction by indomethacin. These findings are cleared in this study, as the activities of CAT and the levels of GSH in stomach and small intestine tissues increased, conciment with a decrease in the levels of MDA and NO after treatment with pulp and seed extracts. These effects occurred due to antioxidant and antiinflammatory effects of pumpkin seed oil which protected the mucosal layer of small intestine and stomach against the inflammatory actions of indomethacin by donating protons through vitamin $\mathrm{C}$ that reacts with ROS and form more stable molecules, so that ulceration signs decreased. This total phenolic content of pumpkin fruit extract had high scavenging activity toward free radicals, $\mathrm{NO}$ and $\mathrm{H}_{2} \mathrm{O}_{2}$ (Attarde et al., 2010). 
Pumpkin oil seed extract alone or with ellagic acid protected rats from methotrexateinduced damage through antioxidant and anti-inflammatory effects. Oral gavage of the oil alone or with ellagic acid for 5 days prior to methotrexate treatment decreased the intestinal damage, serum $\mathrm{PGE}_{2}$, tissue MDA, NO, MPO, XO and adenosine deaminase activities and increased GSH level ( El-Boghdady ,2011).

Al-Okbia et al.(2017) clarified that pumpkin seed oil had a significant antiinflammatory and antioxidant activities due to their content of carotenoids, polyphenols, tocopherol, phytosterols and unsaturated fatty acids. Pumpkin seed oil significantly inhibited the increased plasma level of MDA, thus reducing the severity of inflammation.

Lim (2012) concluded that pumpkin pulp and seed oil extracts contains natural antioxidants like $\beta$-carotene, $\beta$-cryptoxanthine, lutein and zeaxanthine. Also it contains vitamin $\mathrm{C}, \gamma$-tochopherol and phytosterols ( $\beta$-sistosterol). All of these antioxidants scavenge the free radicals produced after administration of indomethacin especially superoxide anion and protect the gastrointestinal cell membranes from lipid peroxidation.

Pumpkin has high phenolic compound including flavonoids, tannins and lignin. The polyphenols have antioxidant activities due to their strong capacity to donate electrons or hydrogen atoms and can directly scavenge ROS (Arora et al., 2000).

\section{Conclusion}

This study revealed that, oral administration of pumpkin pulp and / or oil seeds extracts are beneficial inducing a marked protective and improvement effects in biochemical changes induced by indomethacin. These include decrease of the level of lipid peroxidation and NO, gastric volume, free, total acidity and the activities of XO and MPO enzymes .The most beneficial ameliorative effect appeared in the combination of the two extracts (pulp and seeds oil) in the pre dose in almost all parameters as it contains high concentration of phenolic compounds that combat the free radicals produced after exposure to indomethacin. 
Table (1): Influence of the oral administration of pumpkin (Cucurbita moschata) pulp and / or seeds oil extracts on gastric volume, total and free acidity in rats.

\begin{tabular}{|c|c|c|c|}
\hline \multirow{2}{*}{ Groups } & \multicolumn{3}{|c|}{ Biochemical analysis in stomach } \\
\hline & Gastric volume & Total acidity & Free acidity \\
\hline Group 1: NCG & $0.36 \pm 0.03^{a}$ & $14.09 \pm 1.58^{a}$ & $5.59 \pm 1.25^{\mathrm{a}}$ \\
\hline Group 2: PG & $1.25 \pm 0.14^{b}$ & $34.93 \pm 0.95^{b}$ & $10.26 \pm 1.11^{b}$ \\
\hline Group 3: PPG & $0.45 \pm 0.03^{c}$ & $20.11 \pm 1.34^{c}$ & $8.24 \pm 0.47^{\mathrm{c}}$ \\
\hline Group 4: PSG & $0.48 \pm 0.03^{c}$ & $23.56 \pm 1.13^{c}$ & $7.69 \pm 0.22^{c}$ \\
\hline Group 5: PPSG & $0.81 \pm 0.03^{c}$ & $21.10 \pm 1.64^{c}$ & $8.03 \pm 0.58^{c}$ \\
\hline Group 6: IPG & $0.67 \pm 0.03^{c}$ & $22.15 \pm 0.88^{c}$ & $7.11 \pm 0.37^{c}$ \\
\hline Group 7: ISG & $0.77 \pm 0.05^{c}$ & $18.51 \pm 1.25^{c}$ & $7.59 \pm 0.37^{\mathrm{c}}$ \\
\hline Group 8: IPSG & $0.65 \pm 0.07^{\mathrm{c}}$ & $24.19 \pm 0.43^{c}$ & $7.70 \pm 0.48^{c}$ \\
\hline LSD & 0.061 & 1.210 & 0.699 \\
\hline
\end{tabular}

- Values are expressed as mean $\pm \mathrm{SD}, \mathrm{n}=12$

- There was no significant difference between means have the same alphabetical superscripts letter in the same column $(P<0.05)$. 
Table (2): Effect of oral administration of pumpkin (Cucurbita moschata) pulp and / or seeds oil extracts on xanthine oxidase (XO) and myeloperoxidase (MPO) activities in small intestine of rats.

\begin{tabular}{|c|c|c|}
\hline \multirow{2}{*}{ Groups } & \multicolumn{2}{|c|}{ In small intestine } \\
\hline & $\begin{array}{l}\text { Xanthine oxidase } \\
\text { (ng/100mg) (XO) }\end{array}$ & $\begin{array}{c}\text { Myeloperoxidase } \\
\text { (ng/100 mg) (MPO) }\end{array}$ \\
\hline Group 1: NCG & $0.50 \pm 0.05^{\mathrm{a}}$ & $44.95 \pm 1.25^{\mathrm{a}}$ \\
\hline Group 2: PG & $6.04 \pm 0.43^{b}$ & $70.08 \pm 1.03^{b}$ \\
\hline Group 3: PPG & $4.95 \pm 0.29^{c}$ & $66.52 \pm 1.15^{c}$ \\
\hline Group 4: PSG & $4.78 \pm 0.08^{c}$ & $67.18 \pm 0.55^{c}$ \\
\hline Group 5: PPSG & $4.74 \pm 0.09^{c}$ & $60.81 \pm 1.08^{c}$ \\
\hline Group 6: IPG & $4.92 \pm 0.06^{c}$ & $63.19 \pm 0.67^{c}$ \\
\hline Group 7: ISG & $4.69 \pm 0.09^{c}$ & $61.24 \pm 0.60^{c}$ \\
\hline Group 8: IPSG & $4.33 \pm 0.10^{c}$ & $56.92 \pm 0.73^{c}$ \\
\hline LSD & 0.196 & 0.920 \\
\hline
\end{tabular}

- Values are expressed as mean $\pm \mathrm{SD}, \mathrm{n}=12$.

- There was no significant difference between means have the same alphabetical superscripts letter in the same column $(P<0.05)$. 
Table (3): Effect of oral administration of pumpkin (Cucurbita moschata) on malondialdehyde (MDA) and nitric oxide (NO) levels in the small intestine and stomach tissues in rats.

\begin{tabular}{|c|c|c|c|c|}
\hline \multirow[b]{2}{*}{ Groups } & \multicolumn{2}{|c|}{ In small intestine } & \multicolumn{2}{|c|}{ In stomach } \\
\hline & $\begin{array}{c}\text { Malondialdehyde } \\
\text { (nmol/g. tissue) } \\
\text { (MDA) }\end{array}$ & $\begin{array}{l}\text { Nitric oxide } \\
\qquad(\boldsymbol{\mu ~ m o l} / \mathrm{g})\end{array}$ & $\begin{array}{c}\text { Malondialdehyde } \\
\text { (nmol/g. tissue) } \\
\text { (MDA) }\end{array}$ & $\begin{array}{l}\text { Nitric oxide } \\
\qquad(\mu \mathrm{mol} / \mathrm{g})\end{array}$ \\
\hline Group 1: NCG & $11.94 \pm 0.58^{a}$ & $4.03 \pm 0.52^{\mathrm{a}}$ & $10.09 \pm 0.66^{a}$ & $4.59 \pm 0.24 a$ \\
\hline Group 2: PG & $31.00 \pm 1.00^{b}$ & $22.53 \pm 1.2^{b}$ & $33.46 \pm 0.57^{b}$ & $20.56 \pm 0.90^{b}$ \\
\hline Group 3: PPG & $18.05 \pm 0.62^{c}$ & $7.96 \pm 0.80^{c}$ & $15.92 \pm 1.12^{c}$ & $10.14 \pm 0.78^{c}$ \\
\hline Group 4: PSG & $15.90 \pm 0.50^{c}$ & $5.28 \pm 0.35^{\mathrm{c}}$ & $11.13 \pm 0.41^{c}$ & $9.22 \pm 0.96^{c}$ \\
\hline Group 5: PPSG & $20.94 \pm 0.65^{c}$ & $6.03 \pm 0.19^{c}$ & $13.43 \pm 1.07^{\mathrm{c}}$ & $8.12 \pm 0.88^{c}$ \\
\hline Group 6: IPG & $17.83 \pm 0.72^{c}$ & $9.39 \pm 0.20^{c}$ & $16.67 \pm 2.26^{\mathrm{c}}$ & $7.01 \pm 0.20^{c}$ \\
\hline Group 7: ISG & $25.01 \pm 0.99^{c}$ & $11.13 \pm 0.42^{c}$ & $20.09 \pm 0.87^{\mathrm{c}}$ & $6.86 \pm 0.12^{c}$ \\
\hline Group 8: IPSG & $21.49 \pm 2.12^{c}$ & $8.02 \pm 0.21^{\mathrm{c}}$ & $19.16 \pm 0.46^{c}$ & $6.21 \pm 0.11^{c}$ \\
\hline LSD & 1.025 & 0.591 & 1.025 & 0.591 \\
\hline
\end{tabular}

- Values are expressed as mean $\pm \mathrm{SD}, \mathrm{n}=12$.

- There was no significant difference between means have the same alphabetical superscripts letter in the same column $(P<0.05)$. 


\section{References}

Abdel-Raheem, I. (2010): Gastroprotective effect of rutin against indomethacin-induced ulcers in rats.J. basic \& clinical. Pharm \& Tox. 107: 742-750.

Adhikary ,B, Yadav, S.K., Roy, K, Bandyopadhyay, S.K. and Chattopadhyay, S. (2011): Black tea and theaflavins assist healing of indomethacin-induced gastric ulceration in mice by anti-oxidative action. Evid-Based Compl Alt Med. 8:1-11.

Aebi, H. (1984): B. Isolation, purification, characterization, and assay of antioxygenic enzymes. Catalase in vitro. Methods in Enzymology. .105:121-126.

Albayrak,A ,Alp,H.H . and Suleyman,H.(2015): Investigation of Antiulcer and Antioxidant Activity of Mocc effect ofobemide in Rats. Eurasian J Med. 47(1): 32-40.

Ali A. and Saddiq N. (2012): Antifungal and prophylactic activity of pumpkin (Cucurbita moschata) extract against Aspergillus flavus and aflatoxin B1. Afr. J. Microbiol. Res.6 (41): 6941-6947.

Al-Okbi, S.Y., Mohamed, D.A., Kandil ,E, Abo-Zeid, M.A., Mohammed, S.E .and Ahmed, E.K.( 2017): Anti-inflammatory activity of two varieties of pumpkin seed oil in anadjuvant arthritis model in rats. Grasas Aceites.Int.Jfats \&oils. 68(1):1-12.

AOAC, (1990): Official methods of analysis, Association of Official Analytical Chemists, Washington DC. USA, 14th edition, p76-86.

Arora, A, Byrem, T.M., Nair, M.G., Strasburg, G.M. (2000): Modulation of liposomal membrane fluidity by flavonoids and isoflavonoids. Arch Biochem Biophys .373(1),102-109.

Attarde, D.L., Kadu, S.S., Chaudhari, B.J., Kale, S.S.and Bhamber, R.S. (2010): In vitro antioxidant activity of pericarp of Cucurbita maxima Duch. Ex Lam. Int.J. PharmTech Res. 2(2) ,1533-1538.

Badr, G.M. and Al-Mulhim, J.A. ( 2014): The protective effect of aged garlic extract on nonsteroidal anti-inflammatory drug-induced gastric inflammations in male albino rats. Evidence-Based Complementary and Alternative Medicine. (3) : 1-9.

Bardaa, S., Ben Halima, N., Aloui, F., Mansour, R.B., Jabeur, H., Bouaziz, M.and Sahnoun,Z.( 2016): Oil from Pumpkin (Cucurbita pepo L.) Seeds: Evaluation of Its Functional Properties on Wound Healing in Rats, Lipids Health Dis. 15(1):1-12.

Berkels , R, Purol-Schnabel , S. and Roesen, R. (2004): Measurement of nitric oxide by reconversion of nitrate/nitrite to NO. J.of Human Press; 279: 1-8.

Beutler ,E, , O and Kelly, M.B. (1963): Improved method for the determination of blood glutathione. J. Lab. Clin. Med. 61:882-888.

Bezerra, D.P., Soares ,A.K.N. and De Sousa, D.P. (2016): Overview of the role of vanillin on redox status and cancer development. Oxidative medicine and cellular longevity.1-9. 
Bhowmik, D, Chiranjib, T. K., and Pankaj, K. S. (2010): Recent trends of treatment and medication peptic ulcerative disorder. Int J Pharm Tech Research .2(1): 970-80.

Borhade S. (2012): Extraction and characterization of pumpkin (Cucurbita mixta) seed oil. Life sciences Leaflets, 45-49.

Chen, J, Small-Howard ,A, Yin ,A. and Berry, M.J.( 2005): The responses of Ht22 cells to oxidative stress induced by buthionine sulfoximine (BSO). BMC Neurosci. 6(1):1-8.

Cryer, B. and Feldman, M. (1998): Cyclooxygenase-1 and Cyclooxygenase-2 selectivity of widely used non-steroidal anti-inflammatory drugs. Am. J. Med., 104:413-21.

Dhasan P.B., Jegadeesan M. and Kavimani S. (2010): Antiulcer activity of aqueous extract of fruits of Momordica cymbalaria Hoof F. in Wistar rats. Pharmacogn. Res. 2(1):58-61.

Draper, H. H. and Hadley, M. (1990): A review of recent studies on the metabolism of exogenous and endogenous malondialdehyde. Xenobiotica, 20(9): 901-907.

El-Ashmawy, N.E,Khedr,E.G.,El-Bahrawy,H.A and Selim,H.M.(2016)a: Nebivolol prevents indomethacin-induced gastric ulcer in rats. 13:580-589.

El-Ashmawy,N.E, Khedr, E.G.,Hoda A. El-Bahrawy and Hend M. Selim,H.M.(2016)b: Nebivolol prevents indomethacin induced gastric ulcers in rats. Journal of Immunotoxicology.14 (3):671-678.

El-Aziz A.B and El-Kalek H.A.(2011) :Antimicrobial proteins and oil seeds from pumpkin (Cucurbita moschata).Nature and Science. 9(3):105-119.

EL-Boghdady,N.A.(2011): Protective effect of ellagic acid and pumpkin seed oil against methotrexate- induced small intestine damage in rats. Indian Journal of Biochemistry and Biophysics. 48:380-387.

Furst, D.E., Ulrich, R.W. and Prakash ,S.H. (2011): NSAIDs, disease modifying antirrhumatic drugs, nonopioid analgesics and drugs used in gout. In: Katzung BG (Ed.), Basic and Clinical Pharmacology, pp. 637-638.oxicol. 12: 681-688.

Ghosal,N , Firdaus,S,, Paul,S ,Naaz ,S Chattopadhyay,A, Shukla,P , Jain,G , Pattari,S Rangari.V.D and Bandyopadhyay,D.(2016): Amelioration of gastrotoxic effect of indomethacin by piperine in male wistar Rats. Journal of Pharmacy Research .10:240-254.

Guha,D and Sarkar ,S.(2008) : Effect of ripe fruit pulp extract of Cucurbita Pepo Linn in aspirin induced gastric and duodenal ulcer in rats.Indian J Exp Biol .46(9):639-645.

Halici,M.B., Odabasoglu,F, Suleyman,H . and Bayir,Y.(2005): Effects of water extract of Usena longissima on antioxidant enzyme activity and mucosal damage causedby indomethacin in rats.Pub Med.12:656-662. 
Hernández-Santos, B，Rodríguez-Miranda，J，HermanLara ,E，Torruco-Uco，J.G., Carmona-García ,R, Juárez-Barrientos ,J.M., Chávez-Zamudio and R, Martínez-Sánchez, C.E.(2016): Effect of oil extraction assisted by ultrasound on the physicochemical properties and fatty acid profile of Pumpkin seed oil (Cucurbita pepo), Ultrason. Sonochem. 31: 429-436.

Kalita, J, Chauhan, P. S., Mani, V. E., Bhoi, S. K., and Misra, U. K. (2015): VEGF and its receptors in dengue virus infection. J. med virol, 87(9): 1449-1455.

Karmes, E. and Haris ,R.S. (2006): General Discussion on the stability of nutrients. Elvis publishers $.560-561$.

Kumar A, Ashwlayan V, Verma M.(2019): Diagnostic approach \& pharmacological treatment regimen of Peptic Ulcer Disease. Phar Pharm Res Open Acc J. 1(1):1-12.

Levesque R. (2007): SPSS programming and Data Mangement: A Guide for SPSS and SAS Users $4^{\text {th }}$ ed .SPSS Inc, Chicago, IL.

Lim , T.K.(2012) :Edible medicinal and non-medicinal plants. Springer, Dordrecht. (2):268-273.

Loizou, S, Lekakis, I, Chrousos, G.P. and Moutsatsou , P.(2010): Beta-sitosterol exhibits antiinflammatory activity in human aortic endothelial cells. Mol Nutr Food Res.54:551- 558.

Miura, T, Muraoka, S and Fujimoto, Y. (2002): Lipid peroxidation induced by indomethacin with horseradish peroxidase and hydrogen peroxide: involvement of indomethacin radicals. Biochem. Pharmacol. 63: 2069-2074.

Mohamed ,M.M. and Abd El-fattah,H.(2014): Attenuation of Aspirin-Induced Gastric Ulcer in Rats By Linseed, Pumpkin and Lupine Seed Oils. Indian Journal of Applied Research.10:586590.

Musalmah ,M, Fairuz,A.H., Gapor, M.T. and Ngah ,W.Z. (2002): Effect of vitamin E on plasma malondialdehyde, antioxidant enzyme levels and the rates of wound closures during wound healing in normal and diabetic rats. Asia Pacific J Clin Nutr. 11:S448-551.

Raji, Y, Oyeyemi ,W. A., Shittu, S.T. and Bolarinwa, A. F. (2011): Gastro-protective effect of methanol extract of Ficus asperifolia bark on indomethacin-induced gastric ulcer in rats. Nig. J. Physiol. Sci. 26(1):43 - 48.

Roelofs L. (2006): Tissue Plasminogen activator modulates inflammatory responses and renal function in ischemia reperfusion injury. J Am Soc Nephrol .17(1):131-140.

Sadi ,G. (2015): Resveratol improves hepatic insulin, Signaling and Reduces the inflammatory response in Streptozotocin -Induced Gene, 570 :213-220.

Shim ,Y.K., Kim, N. (2016) : Nonsteroidal anti-inflammatory drug and aspirin-induced peptic ulcer disease. Korean J Gastroenterol .67: 300-312. 
Sivalingam , N, Hanumantharaya , R, Faith , M, Basivireddy , J, Balasubramanian, K.A. and Jacob, M. (2007): Curcumin Reduces Indomethacin-Induced Damage in the Rat Small Intestine. J. Appl. Toxicol. 27: 551-560.

Srikanth J and P.Muralidharan. (2009): Anti-ulcer activity of MorindaCitrifolia Linn fruit extract. J.Sci.Res. 1:345-352.

Suzuki, H, Nishizawa, T, Tsugawa, H, Mogami ,S. and Hib ,T. (2012): Roles of oxidative stress in stomach disorders. J Clin Biochem Nutr. 50:35-39.

Szabo, S, Trier, J. S, Brown, A, Schnoor, J, Homan, H. D. and Bradford, J. C. (1985): A quantitative method for assessing the extent of experimental gastric erosions and ulcers. $\mathrm{J}$ of Pharmacol Methods, 13(1), 59-66.

Tahiliani P, Kar A. (2000): Role of moringaoleifera leaf extract in regulation of thyroid hormone status in adult male and female rats. pharmacol Researsh. 41(3):319-323.

Tripathi ,K.D.(2009): Essentials of medical pharmacology, New Delhi. 6th edition Jaypee Brothers Publishers (P) Ltd., Medical .627-638.

Ucar A,SakSD and Melli M. (1998): Effects of Chronic Treatment with Indomethacin at Clinically Relevant Doses on Intestinal Tissue 6-Keto Prostaglandin F $1 \alpha$ and Leukotriene B 4 Level in Relation to Gastroenteropathy. Inflammation.22 (3): 243-252.

Xavier, A. A. O. and Pérez-Gálvez, A. (2016): Carotenoids as a Source of Antioxidants in the

Diet. In Carotenoids in Nature .Springer, Cham.79:359-375.

Zinash, A., Workneth, T.S. and Woldetsadk, K. (2013): Effects of accessions on the Chemical quality of fresh pumpkin. Afr. J. Biotechnol. 12: 7092-7098. 


\section{الملخص باللغة العربية}

تقييم مستخلصات لب وبذور القرع العلى على قرح الجهاز الهضمى المحثثة بواسطة الاندومثاسين فى الجرذان

\section{كريمة يحيى جاد* تهانى السيد خليف" هبة بركات" شيماء المصرى"}

*قسم الكيمياء الحيوية و التخذية - كلية البناتـ جامعة عين شمس

تعتبر القرحة الهضمية واحده من الامر اض الأكثر شيو عاوخاصه عند كبار السن، نتيجة الاستخدام المستمر للمسكنات الغير استيرودية ومضادات الالتهاب لفنرات طويلة . حاولت هذه الدراسة تقييم التاثثر الوقائى و المحسن لتناول كلا من المستخلص المائى للب و المستخلص الكحولى عن طريق الفم لبذور القرع العسلى على قرح الجهاز الهضمى الهحدثة بواسطة الاندوميثاسين المتناول عن طريق الفم فى الجرذان .. اظهرت النتائج زيادة فى حجم العصير المعدى وحموضة المعدة الكلية والحرة و ارتفاع فى الانثطة الانزيمية للز انثين اوكسيداز و الميلوبيرواوكسيداز و اكسدة الدهون و التى ظهرت بزيادة معدلات اكسيد النيتريك والمالون داى الدهيد وزيادة معدلات الجلوتاثيون المختزل ونشاط انزيم الكتاليز. العلاجات بمستخلصات لب وبذور القرع العسلى لها ناثير محس ووقائى على القناة الهضمية بالمقارنة مع المجموعة المريضة التى تعاطت الاندوميثاسين بدون معالجة. 